ВАН СЯОФЕЙ

\title{
АКТУАЛЬНІ ПРОБЛЕМИ ПЕДАГОГІЧНОЇ ОСВІТИ УЧИТЕЛІВ ФІЗИЧНОЇ КУЛЬТУРИ КИТАЙСЬКОЇ НАРОДНОЇ РЕСПУБЛІКИ
}

\author{
(СВан Сяофей, 2019 \\ https://orcid.org/0000-0002-8108-6349 \\ http://doi.org/10.34142/2312-2471.2019.62.06
}

У статті йде мова про дослідження впливу отриманої педагогічної освіти на ефективність подальшої викладацької роботи в різних педагогічних закладах КНР. У КНР, як правило, відбувається навчання перед працевлаштуванням на посаду вчителя, так і навчання безпосередньо під час роботи. Мета циих заходів - дати майбутнім учителям можливість оволодіти знаннями $і$ здібностями, необхідними для навчання та управління класами, $i$ в кінцевому підсумку сприяти розвитку особистих педагогічних навичок. Освіту до працевлаштування також називають педагогічною, яка $\epsilon$ відмінною формою вищзої освіти з моменту заснування Нового Китаю. Статус вчителя до працевлаштування забезпечується безпосередньо рівнем навчання у закладі освіти з наступним отриманням відповідного ступеня, мотивацією в навчанні відповідного рівня установи, щуо надає ступінь, напрям академічної освіти за професійним спрямуванням, кваліфікацію та бажання продовжувати навчання на робочому місиі. Ефективність вирішення такого питання була з'ясована за допомогою самозвіту респондентів. Результати дослідження вказують на те, щзо академічна кваліфікація викладачів в основному відповідає стандарту, але кількість викладачів з окремих предметів, в тому числі й з фізичного виховання, все ж таки є недостатньою. Рівень освіти більшості вчителів в основному відповідає вимогам підготовки, однак кількісний показник все ще потребує корегування. В початкових $i$ середніх школах КНР існує серйозна нестача вчителів фізкультури, щуо різко контрастує з проханням уряду збільшити курси $i$ заняття з фізичного виховання та основ здоров'я. Тому в майбутньому КНР необхідно змінити концепції $i$ зосередитися на підготовці саме вчителів фізичної культури. Отримані результати можуть бути корисними для тих установ, які в даний час працюють над збільшенням кількості професійних курсів підготовки вчителів з відповідною кількістю годин навчання.

Ключові слова: освіта, учитель фізичної культури, КНР, працевлаштування, мотивація, кваліфікація, стандарт.

\section{Wang Xiaofei. Current Problems of Pedagogical Education of Physical Training Teachers in China}

The research about the impact of pedagogical education on the effectiveness of further teaching in various pedagogical institutions in China is studied in the article. As a rule, in China there is a training process before a teacher's employment, and there is a training process directly during work. The purpose of these activities is to 
give future teachers the opportunity to acquire the knowledge and skills needed to teach and manage as well as to promote the development of personal pedagogical skills. The education before employment is also called pedagogical, which is an excellent form of higher education since New China founding. The status of a teacher before employment is provided directly by the education level in the educational institution with the obtaining the appropriate degree which is followed, motivation in teaching at the appropriate institution, it provides the degree and the direction of academic education, professional qualifications and desire to continue training while working. The effectiveness of this issue was ensured through the respondents' selfreport. The results of the study indicate that the teachers' academic qualifications generally meet the standard, but the number of teachers in certain subjects, including physical education teachers, is still insufficient. The education level of most teachers generally meets the training requirements, but the quantitative indicator still needs to be adjusted. There is a serious shortage of physical education teachers in primary and secondary schools, in stark contrast to the government's request to increase physical education and health courses and classes. Therefore, in the China future it is necessary to change concepts and focus on the training physical education teachers. The results obtained may be useful for those institutions that are currently working to increase the number of professional teachers' training courses with the appropriate number of academic hours.

Key words: education, physical education teachers, China, employment, motivation, qualification, standard.

Постановка проблеми. Для уряду Китайської Народної Республіки (КНР) академічна кваліфікація і статус вчителів завжди були важливим аспектом діяльності Міністерства освіти, провінційних та муніципальних відділів управління освітою. У КНР, як правило, відбувається навчання перед прийомом на роботу на посаду вчителя, так і навчання безпосередньо під час роботи. Мета цих заходів - дати майбутнім учителям можливість оволодіти знаннями і здібностями, необхідними для навчання та управління класами, і в кінцевому підсумку сприяти розвитку особистих педагогічних навичок. Освіту до працевлаштування також називають педагогічною, яка $є$ відмінною формою вищої освіти з моменту заснування Нового Китаю.

Аналіз останніх досліджень і публікацій. Дослідники провели багато досліджень 3 цього питання. Ці дослідження охоплюють безліч галузей, пов'язаних $з$ процесом навчання, таких як організація системи освіти, мета підготовки, параметри навчального плану і безпосередньо реалізація навчання у КНР. Серед них особливо багато уваги приділяється питанню обговорення формуванню навчального плану. Чимало авторів в своїх роботах досліджувало проблеми різних рівнів освіти Китайської народної республіки [Н.Боревська, 2011; С.Гала, 2011; І.Животовська, 2007; В.Лунячек, 2013; Су Цзюньянь, 2011; Сяо Сy, 2011].

Проте, в абсолютній більшості періодичних наукових видань України система освіти в КНР висвітлюється вкрай обмежено. Одним 3 джерел, що 
досить регулярно друкує матеріали щодо китайської системи освіти є журнал «Педагогіка» [Су Цзюньянь, 2011; Н.Боревська, 2011], але найбільше переважають електронні джерела [„,Освіта в Китаї”, 2009-2013; „Система освіти в Китаі”, 2007; „Національна довгострокова реформа”, 2013].

Виділення невирішених раніше частин загальної проблеми. Однак, незважаючи на десятиліття дискусій, фахівці все ще не дійшли єдиної думки 3 певних питань. Це такі питання як співвідношення предметних курсів у навчальних планах, правильність i ефективність проведення освітнього навчання та стажування, а саме - аналіз проблеми педагогічної освіти учителів фізичної культури КНР.

Метою даної статті є визначення впливу отриманої педагогічної освіти на ефективність подальшої викладацької роботи в різних педагогічних закладах.

Виклад основного матеріалу. Статус вчителя до працевлаштування забезпечується безпосередньо рівнем навчання у закладі освіти 3 наступним отриманням відповідного ступеня, мотивацією в навчанні відповідного рівня установи, що надає ступінь, напрям академічної освіти за професійним спрямуванням, кваліфікацію та бажання продовжувати навчання на робочому місці.

Ефективність вирішення такого питання аналізується нами у дослідженні, вона була забезпечена за допомогою самозвіту респондентів за п’ятьма рівнями оцінки від високого до низького: «дуже добре», «добре», «загально», «погано» i «дуже погано»". Звичайно, педагогічна ефективність вчителів може бути відображена в багатьох аспектах спостереження та інформації, але наше дослідження обмежено змістом анкети з визначеними вище питаннями щодо статусу вчителя, тож використовується інформація, повідомлена особисто.

Ефективна вибірка цього опитування у КНР складає 11190 осіб, вибірка вчителів початкових, середніх і старших класів відповідно 5882, 3727 та 1581, що становить 52,6\%, 33,3\% i 14,1\% від загальної вибірки відповідно. Анкета використовує метод стратифікованої вибірки 3 використанням допоміжних даних офіційної статистики, опублікованих Міністерством освіти КНР. Зразки взяті 3 дев'яти провінцій i автономних областей: Хейлунцзян, Тяньцзінь, Ганьсу, Хубей, Сичуань, Гуансі, Цзянсу, Шаньдун і Шанхай.

Наприклад, дані, опубліковані Міністерством освіти у 2008 році, показують, що в 2007 році в звичайних початкових і середніх школах було зайнято 10,52 мільйона вчителів, які працюють на повну ставку, в тому числі 5,613 мільйона в початкових школах, 3,464 мільйона в середніх школах і 1,443 мільйона в старший школі. Це означає, що вибірка цього опитування $\epsilon$ достатньо інформативною. При аналізі даних для розрахунку використовується статистичне програмне забезпечення SPSS16.0. Результати опитування показують, що частка вчителів початкових і середніх шкіл КНР, які здобули вищу освіту і працюють в молодших класах середньої школи становить 0,3\%, в технічних середніх школах 7,5\%, технікумах або старших класах середньої 
школи, в молодших класах середньої школи 35,7\%, в бакалавраті 55,7\% та 0,8\% серед випускників.

Можна бачити, що здобуття вищої освіти є актуальним для кожного вчителя. У той же час, опитування також показало ще один цікавий феномен: частка цих вчителів зі ступенем становить лише 17,3\%. Іншими словами, 3 $55,7 \%$ вчителів зі ступенем бакалавра, тільки $17,3 \%$ вчителів мають вищу ступінь. Можна припустити, що вищу освіту майже дві третини вчителів здобули до працевлаштування, а інші заочно під час перебування на робочому місці.

Дивлячись на початковий шкільний рівень, ситуація інша. Наявність вищої освіти до працевлаштування серед вчителів початкових класів i навчальних курсів виглядає наступним чином: молодші класи середньої школи складають 0,2\%, технікуми, технічні коледжі та середня школа склали 13,3\%, молодші коледжі - 51,2\%, студенти бакалаврату - 35,1\%, аспіранти - 0,2\%.

Серед вчителів середньої школи: молодші класи 0,4\%, технікум або середня школа 1,3\%, молодші коледжі 25,0\%, бакалаврат 72,6\% та випускники 0,7\%. Відповідна кількість серед вчителів старших класів і курсів: в молодших класах середньої школи $0,5 \%$, в технікумах коледжах або старших класах середньої школи 0,3\%, в молодших класах середньої школи 3,4\%, в бакалавраті $92,6 \%$ та $3,3 \%$ в аспірантурі.

Опитування також показало, що частка вчителів початкових шкіл, вчителів молодших класів середньої школи і вчителів старших класів зі ступенями склала 5,3\%, 18,1\% і 59,9\% відповідно. У порівнянні з їх ступенем бакалавра або вище, розриви становлять 30,0\%, 55,2\% і 36,0\%. Очевидно, що у вчителів молодших класів середньої школи найбільший розрив.

Місцеві педагогічні коледжі є основними закладами підготовки майбутніх вчителів. Випускники цих коледжів складають 76,1\%, 63,2\% і 59,1\% вчителів середньої, молодшої і початкової шкіл відповідно. На додаток до місцевих коледжів та інших типів установ, таких як звичайні університети, безпосередньо підпорядковані Міністерству освіти, існують, так звані «незвичайні» зарубіжні школи, коледжі, а також приватні коледжі та університети. Але, все ж таки місцеві педагогічні коледжі, як і раніше, $\epsilon$ основними навчальними закладами для вчителів базової освіти в Китаї.

Частка вчителів, які закінчили «незвичайні» університети безпосередньо при Міністерстві освіти і місцеві «незвичайні» університети, становить 1,1\% в початкових школах, 4,5\% в молодших і середніх школах, i 7,8\% в середніх школах, що показує, що відкрита система педагогічної освіти, яку намагається створити уряд, також не сформувалася. Але виникнення «незвичайні» коледжів уряд оголосив важливою рушійною силою в педагогічній освіті в Китаї.

В цілому, розподіл академічної освіти вчителів за професійним спрямуванням в основному відповідає предметній спрямованості різних рівнів шкіл. Серед вчителів початкових шкіл частка китайських мовних спеціальностей є найвищою - 37,4\%, за нею йдуть початкова освіта $(20,8 \%)$, педагогіка $(9,2 \%)$ і математика $(5,1 \%)$. Основна причина більшості китайських 
професійних вчителів полягає в тому, що мовні курси в початковій школі $\epsilon$ відносно найбільш поширеними.

В останні роки реформи педагогічної освіти торкнулися більш за все початкової шкільної освіти і педагогіки. Фактично, викладачі, які володіють цими двома спеціальностями, можуть викладати як китайську мову, так i математику, англійську та інші предмети. Серед вчителів молодших класів середньої школи порядок професійного розподілу вчителів - китайська мова $(28,3 \%)$, іноземна мова $(16,3 \%)$, математика $(14,3 \%)$, фізика $(5,9 \%)$, політика $(4,9 \%)$, спорт $(4,0 \%)$, історія $(3,7 \%)$, хімія $(3,5 \%)$, мистецтво $(3,5 \%)$.

Цей розподіл в основному відповідає розподілу годин занять 3 кожного предмету в середній школі. Дивно, що частка годин біології становить всього 2,0\%, що незрівнянно з часткою навчальних годин за планом навчальної програми. Відповідно до плану розробки загальноосвітніх програм обов'язкової освіти біологія повинна бути еквівалентна предмету «фізика».

Крім того, частка вчителів за спеціальностями «Історія» $є$ відносно низькою, а частка китайських мовних спеціальностей занадто висока. Серед вчителів старших класів - професійний розподіл вчителів по зростанню китайська мова (20,0\%), іноземна мова (14,4\%), математика $(14,2 \%)$, історія $(6,8 \%)$, фізика $(6,6 \%)$, хімія $(6,3 \%)$, біологія $(5,7 \%)$, політика $(5,6 \%)$, географія $(4,3 \%)$, мистецтво $(3,7 \%)$, комп'ютер $(3,5 \%)$, спорт $(3,0 \%)$.

Очевидно, що частка вчителів 3 трьох предметів (китайської мови, математики та іноземної мови) найвища. Відповідно до плану китайської навчальної програми для старших класів, порядок годин з кожного предмета від високого до низького: китайська мова, математика та англійська мова, потім фізика, хімія, історія, географія, спорт і здоров'я, політика і біологія. 3 цього порівняння ми можемо виявити, що частка годин занять з більшості предметів в основному відповідає професійній підготовці вчителів.

Варто зазначити, що чи є це початкова або середня школа, частка годин занять $з$ фізичного виховання та здоров'я досить велика, але частка вчителів, які мають відповідну освіту недостатня. Причин такої ситуації може бути дві: одна з них полягає в тому, що школа не надає достатньої кількості годин з фізичного виховання відповідно до плану навчальної програми, звичайно, для цього не потрібно занадто багато професійних вчителів 3 фізичного виховання. Подруге, вчителя, що отримують освіту за іншими спеціальностями, викладають фізичне виховання.

Переважна більшість працюючих вчителів мають кваліфікаційні атестати. Вчителі старших класів та вчителі початкової школи, які не отримали кваліфікаційні атестати, становить лише 2,3\% і 1,3\% відповідно. Це означає, що в професійному зростанні вчителів початкових і середніх шкіл в Китаї було досягнуто значного прогресу.

Предметний розподіл кваліфікаційних сертифікатів вчителів на всіх рівнях в основному відповідає відповідному рівню навчального плану i вимогам до предметної області. У старшій школі 9 основних дисциплін китайська мова $(19,1 \%)$, математика $(14,2 \%)$, іноземна мова $(13,7 \%)$, хімія 
$(7,7 \%)$, фізика $(6,9 \%)$, історія $(6,7 \%)$, політика $(6,2 \%)$, географія $(4,9 \%)$, інші $(9,9 \%)$.

У молодших класах середньої школи 6 основних предметів - китайська мова $(24,9 \%)$, математика $(20,6 \%)$, іноземна мова $(16,3 \%)$, фізика $(7,2 \%)$, політика $(5,7 \%)$ та інші $(4,3 \%)$. У початковій школі 4 основні предмети китайська мова (39,3\%), математика $(33,7 \%)$, інші $(4,8 \%)$ і музика $(4,1 \%)$. Цікаво відзначити, що частка «інших» варіантів відносно висока на трьох шкільних рівнях. Це пояснюється відсутністю в анкеті деяких предметів, які викладають вчителі, тому їх відповіді відносяться до пункту «інші».

Суть професійної підготовки вчителів до працевлаштування і навчання на робочому місці в основному полягає в тому, щоб опанувати різні курси, що тісно пов'язані з засвоєнням педагогічних знань і навичок. Опитування показує, що з восьми запропонованих навчальних курсів переважна більшість вчителів в школах всіх рівнів взяли участь в навчанні лише в декількох $з$ цих курсів.

Частка тих, хто взагалі не брав участі, становить $1,1 \%$ в групі початкової школи, 0,6\% в групі молодших класів середньої школи і 0,8\% в групі старших класів. Це показує, що впровадження таких навчальних курсів на етапі академічної освіти є відносно добрим. Вчителі шкіл на всіх рівнях освіти мають невелику різницю участі в різних навчальних курсах. Рейтинг навчальних курсів від найвищого виглядає наступним чином: психологія, принципи педагогіки, навчальні матеріали та методи навчання, педагогічна практика, педагогічні навички та технології навчання.

Це відображає більшу схожість між навчальною програмою для вчителів початкових і середніх шкіл та навчальною програмою підготовки вчителя.У Китаї навчання нових вчителів на робочому місці є необхідним заходом, яку здійснюють провінції і міста. Міністерство освіти видало наказ № 7 «Положення про безперервну освіту вчителів початкових і середніх шкіл», виданий у вересні 1999 року, в якому вказувалося, що час підготовки нових учителів має становити не менше 120 годин.

Так відсоток вчителів початкової школи, які не брали участі в навчанні, становила $15,3 \%$, в молодших класах середньої школи - 10,5\%, в групі старших класів $-10,5 \%$. Також не є однаковою співвідношення вчителів шкіл, які брали участь у навчанні. У групі початкової і молодшої середньої школи найвища частка, яка становить $31,1 \%$ і $30,9 \%$ відповідно, тоді як в групі старших класів $37,2 \%$. Проте, отримані результати не є оптимістичними. Професійний статус нових викладачів в школах все ще далекий від необхідного. В цілому, навчання нових вчителів на робочих місцях на всіх рівнях не відповідає встановленим вимогам.

Крім того, також можна зазначити, що соціальний і економічний статус вчителів не $є$ основними факторами, що впливають на мотивацію викладання. Фактором, який дійсно відображає суб'єктивну мотивацію вчителів до професійного зростання, є уподобання «їх власного ідеалу». Цей фактор займає основне місце на всіх рівнях освіти. 
Цікавим також є взаємозв'язок професійної освіти вчителів та навчальних предметів, які вони викладають. У початковій школі вчителі, які закінчили курси китайської мови, математики та іноземних мов, складають найбільшу частку. Наступними йдуть учителі, які мають фахову спеціальну освіту також 3 китайської мови, математики та англійської мови. Це показує, що серед вчителів початкових класів вчителі трьох основних предметів більш послідовні в своєму навчанні і більш професійно підібрані.

Варто зазначити, що фізичне виховання викладається вчителями, які мають зовсім іншу фахову освіту. Випускники факультетів фізичного виховання складають лише $4,1 \%$. Це означає, що фізичну культуру викладають інші за фахом вчителі, і це пояснює відсутність професійних вчителів фізкультури.

У молодших класах середньої школи вчителі основних предметів, таких як китайська мова, математика, англійська мова, фізика, хімія, історія, географія, ідеологія і мораль в основному отримують освіту за відповідною спеціальністю 3 можливістю іiі подальшого продовження. Серед вчителів ідеологічних предметів частка випускників за спеціальностями філософії вище, ніж частка випускників з політичних наук. Варто також відзначити, що серед вчителів фізичної культури найбільш зайнятими $\epsilon$ випускники «інших спеціальностей $з$ суспільних наук», а потім йдуть випускники спеціальностей 3 фізичного виховання.

У середній школі більшість основних предметів викладаються випускниками відповідних фахових спеціальностей. Цікаво, що тільки 2,0\% випускників спортивних спеціальностей працюють в галузі своєї освіти, 2,2\% займаються історією і соціальними дисциплінами, а 95,8\% займаються «іншими курсами».

Варто також відзначити, що майже половина випускників навчальних програм з педагогіки спеціалізуються на викладанні фізики та хімії. Дані також показують, що чим вище рівень школи, тим вище ступінь узгодженості між курсами вищих навчальних закладів та навчальними планами школи. Іншими словами, чим вище рівень школи, тим вище професіоналізм вчителів.

Висновки. Академічна кваліфікація вчителів КНР в основному відповідає стандарту, але кількість вчителів 3 окремих предметів все ж таки $\epsilon$ недостатньою. Хоча рівень освіти більшості вчителів в основному відповідає вимогам підготовки вчителів, однак кількість вчителів з різних предметів все ще потребує корегування. Перш за все, в молодших класах середньої школи нестача вчителів біології, що вкрай велика і потребує доповнення. По-друге, в початкових і середніх школах існує серйозна нестача вчителів фізкультури, що різко контрастує 3 проханням уряду збільшити курси і заняття 3 фізичного виховання та здоров'я. Тому в майбутньому КНР необхідно змінити концепції і зосередитися на підготовці саме вчителів фізичної культури. Рекомендується збільшити кількість вчителів фізичного виховання для роботи в початкових класах. 
Педагогічні коледжі, як i раніше, $є$ основною ланкою початкової педагогічної освіти, а конкурентна модель педагогічної освіти ще не сформована. Виходячи 3 ситуації, що склалася, переваги нестандартних коледжів в педагогічній освіті ще не стали очевидними, а їх соціальна репутація на ринку педагогічних послуг ще не повністю визнана. Звичайні коледжі, особливо місцеві, як і раніше є основним місцем підготовки вчителів до працевлаштування.

3 одного боку, цей висновок може стати причиною того, що КНР буде продовжувати створювати і підтримувати стандартні коледжі та університети для підготовки вчителів, а з іншого боку, це може стати підставою для зміни політики університетів, що беруть участь в підготовці вчителів, підтримувану урядом. Первісний намір уряду полягав в тому, щоб поступово змінити положення звичайних шкіл в сфері педагогічної освіти, але факти показують, що така мета не була досягнута.

Наведені вище дані показують, що академічна кваліфікація вчителя та його підготовка перед прийомом на роботу, а також навчання вчителя на робочому місці - все це сприяє ефективній вчительській роботи, але з погляду кількості навчальних годин курсу підготовки, це, насправді, не є очевидним. Звичайно, в загальних рисах можна сказати, що вища освіта, підготовка перед прийомом на роботу, визначена кількість годин навчання на робочому місці не $\epsilon$ марними для покращення підготовки вчителів.

Ефективність роботи вчителів, які закінчили аспірантуру, визнана значно вищою, значно вище, ніж у тих, хто викладає у старших курсах і нижче. Це особливо проявляється на рівні початкової і середньої школи та рівні вищої освіти. Але, існує думка, яка ставить під сумнів такий взаємозв'язок, і вважає наявність високоосвічених вчителів початкових i середніх шкіл лише статусною ознакою навчального закладу.

Звичайно, потрібно враховувати, що педагогічний склад школи КНР самостійно визначає результати роботи вчителя, і інформації для зовнішньої оцінки все ще не вистачає. Хоча $є$ дані, що вчителі, які пройшли 4-річний курс підготовки перед прийомом на роботу, мають педагогічну ефективність в середньому незначно вище, ніж вчителі з меншим терміном навчання. Така інформація може бути корисною для тих установ КНР, які в даний час працюють над збільшенням кількості професійних курсів 3 відповідною кількістю годин підготовки.

Перспективи подальших розвідок у цьому напрямі. До перспективних напрямів досліджень у цьому напрямку відносимо подальше детальне вивчення механізмів реформування галузі підготовки вчителів фізичної культури Китаю 3 наступним використанням позитивного досвіду в системі освіти України.

\section{Лimepamypa}

1. Боревская Н.Е. Тенденции развития образования в КНР. Педагогика. 2011. №7. C.109-119. 
2. Гала С.В. Із досвіду реформування вищої освіти Китаю. Економіка i держава. 2011. №8. С.52-55.

3. Джгун Н.М. Підготовка майбутніх учителів до виховної роботи в університетах Китайської Народної Республіки [Текст] : автореф. дис. ...канд. пед.наук : 13.00.04. Х., 2012. 20с.

4. Дін Сінь. Психологічний супровід соціальної адаптації китайських студентів в Україні [Текст] : автореф. дис. ...канд. психол. наук : 19.00.07 Одеса, 2009. 20c.

5. Животовская И.Г. Реформа высшего образования в Китае: проблема підготовки кадров. Экономика образования. 2007. №5. С.60-69.

6. Лунячек В.Е. Сучасна освіта Китаю: проблеми і перспективи розвитку. Постметодика. 2013. №1. С.47-54.

7. Освіта в Китаї [Електронний ресурс]. Режим доступу : http://www.geograf.com.ua/china/634-china-education

8. Система освіти в Китаї [Електронний ресурс]. Режим доступу : http://www.movi.com.ua/kitayska-mova/1694-sistema-osviti-kitayu

9. Су Дзюньянь, Сяо Су. Основные формы и тенденции развития системы инспектирования и оценки школ в Китае. Педагогика. 2011. №1. С.94-102.

10. 国家中长期教育改革和发展规划纲要 （2010-2020年） [Національна довгострокова реформа і план розвитку освіти (2010-2020р.)] [Електронний pecypc] 新华社北京 7 月 29 日电. Режим доступу : http://www.gov.cn/jrzg/201007/29/content_1667143.htm

\section{References}

1. Borevskaya, N.E. (2011). Trends in the development of education in China. Pedagogy, 7, 109-119.

2. Gala, S.V. (2011). From the experience of reforming higher education in China. Economy and State, 8, 52-55.

3. Zhgun, N.M. (2012). Preparation of future teachers for educational work in universities of the People's Republic of China: author's ref. dis. ... cand. pedagogical sciences: 13.00.04, Kharkiv, 20.

4. Ding, Xin. (2009). Psychological support of social adaptation of Chinese students in Ukraine: author's ref. dis. ... cand. psychol. Sciences: 19.00.07, Odessa, 20 .

5. Zhivotovskay, I.G. (2007). Reform of higher education in China: the problem of training. Economics of education, 5, 60-69.

6. Lunyachek, V.E. (2013). Modern education in China: problems and prospects for development. Postmethodology, 2013, 1, 47-54.

7. Education in China [Electronic resource]. Access mode: http://www.geograf.com.ua/china/634-china-education

8. The education system in China [Electronic resource]. Access mode: http://www.Movi.com.ua/kitayska-mova/1694-sistema-osviti-kitayu 
9. Su, Junyan, Xiao, Su. (2011). The main forms and trends in the development of the system of inspection and evaluation of schools in China. Pedagogy, 1, 94-102.

10. 国家 中长期 教育改革 和 发展规划 纲要 (2010-2020) [National longterm reform and education development plan (2010-2020) [Electronic resource / 新华社 北京 7 月 29 日 电. Access mode: http://www.gov.cn/jrzg/201007/29/content_1667143.htm 